\title{
6
}

\section{Local Government and Natural Capital}

\begin{abstract}
This chapter marks a significant change in the book's narrative, as the analysis moves from private citizens to the public sphere. Its starting point is that good government can develop distinctive capabilities to ensure that certain types of goods and services, especially those involving externalities and economic public goods, are provided for persons to use to enhance wellbeing. For some policies, particularly where local residents can improve outcomes by participating in policy design or implementation, local government can do this better than central government. In this context, the chapter explains Ostrom's theory of coproduction of local government services and applies it to regional economic development. The chapter also discusses natural capital. Since ecosystem services provided by the natural environment can be diminished by human activity, investment in natural capital is required to maintain wellbeing.
\end{abstract}

Keywords Natural capital • Externalities • Economic public goods • Co-production $\bullet$ Regional economic development

Previous chapters have examined how private citizens can enhance wellbeing through personal time-use choices, through co-creating culturally valued lives within households and families, through collaboration in institutions of civil society, and through participation as producers and consumers in the market 
economy. This chapter marks a significant change, as the analysis turns to activities in the public sphere, introducing terms such as public sector, public services, public works, public economics, public goods, public policy and the public interest.

Discussion of the public sphere touches on strongly contested debates about the role of government in promoting wellbeing. These debates reflect diverse perspectives between views that favour a more expansive public sector and views that advocate smaller government. The wellbeing economics framework does not address this question directly, but emphasises that the public sector offers distinctive opportunities for private citizens to expand their capabilities for enhanced wellbeing, beyond what they could achieve through voluntary associations and market transactions.

A founding contribution to this insight was made by Mancur Olson (1965). Recall from Chap. 4 that persons can enhance wellbeing by participating in institutions of civil society to collaborate with others in the pursuit of common interests and shared values. Olson's analysis supported that proposition, but also explained that voluntary organisations tend to be limited in what they can achieve. This is because the personal reward to any member offering additional effort to advance the group's mission is reduced as the scale of its activities increases. Olsen therefore concluded, "the larger the group, the less it will further its common interests" (idem, p. 36).

Turning to the market economy, Chap. 5 began by acknowledging two important types of goods and services not well supplied by market firms: transactions involving externalities affecting people not directly involved, and items with the characteristics of an economic public good. Both examples are analysed in this chapter, demonstrating that market firms tend to supply too little or too much of an item with externalities (depending on whether the externalities create additional benefits or cause harm) and tend to supply too little of an economic public good (or perhaps none at all).

Thus, voluntary groups and market firms are unable to provide certain goods and services that enhance wellbeing. This creates room for local and central government to support greater wellbeing by ensuring these gaps are filled. As the following sections explain, this distinctive capability is due to the unique authority of governments to collect taxes and to promulgate legally enforced regulations.

There is no guarantee, of course, that this capability will always be exercised well. Throughout history, there have been oppressive governments acting tyrannically to cause great harm to wellbeing (Locke 1690, Chap. 18). Even in wellfunctioning democracies, just as markets can fail to provide optimal quantities 
of certain goods and services, so too can governments fail to deliver all they could to enhance wellbeing (Buchanan and Tullock 1962; Wolf 1979, 1989; Le Grand 1991). These limitations are an important part of the discussion that follows, but Proposition 16 expresses the core idea that good government can make distinctive contributions to the promotion of wellbeing.

Proposition 16 Good government can develop distinctive capabilities for managing the provision of certain types of goods and services, especially those with externalities or the characteristics of an economic public good.

This chapter focuses on local government (including the governance of large cities), leaving the analysis of central government to Chap. 7. It begins with two sections examining externalities and economic public goods. This lays foundations for the chapter's main section, which analyses the distinctive contribution of local government to promoting wellbeing. This draws on the research of Nobel laureate, Elinor Ostrom, who emphasised the importance of co-production of services by local government and resident communities. It also draws on research exploring how local government can collaborate to strengthen placebased capabilities for wellbeing through regional economic development (Sotarauta 2005; Barca 2009; OECD 2009a, b; Barca et al. 2012; Foray 2015; McCann and Ortega-Argilés 2015).

An important example of a public good is a locality's natural environment. The wellbeing of residents in any given place is affected by items such as air and water quality, green spaces in liveable cities, facilities for outdoor recreation and the management of regional parks. The chapter's fourth section therefore introduces the next use of the capital metaphor in the wellbeing economics framework-natural capital. The chapter finishes with a brief conclusion.

\section{Externalities}

Consider a household that regularly hosts parties involving loud music into the early hours of the morning. The parties are presumably part of the kind of life valued by the household's residents, and the partygoers are there by choice, free to leave if they find the hour too late or the music disagreeable. Thus, the direct participants in this activity - the hosts and their guests — can be presumed to value the experience, but the same may not be true for the neighbours. The noise may interfere with their own enjoyment of an evening at home, or it may interrupt the sleep of children and adults. 
In the language of economics, activities like this create an externality by impacting on others not directly involved (Pigou 1932; Coase 1960; Baumol 1972). The loud music example is a negative externality, since the impacts are harmful, but externalities can be positive. Consider a property developer who purchases a row of derelict warehouses and converts them into quality residential housing. The developer and the buyers of the new homes can be presumed to have greater wellbeing, but the development may improve the quality of life for others in the neighbourhood-a positive externality.

The presence of a market externality is not sufficient reason for government intervention. Coase (1960) pointed out that if property rights concerning the externality are clearly defined, then those affected can negotiate a market transaction to reach some mutually accepted solution, as long as the transaction costs of negotiating and enforcing the agreement are not too high. This is known as the Coase Theorem and is a further illustration of how private persons can use the market economy to advance wellbeing.

The caveat in the Coase Theorem is crucial. The market option is not feasible if the costs of negotiating and enforcing agreements are too high, which is likely to be the case when the number of persons involved is large. Thus, an externality involving many people is typically an example of market failure, meaning that the market economy cannot be relied upon to produce a Pareto efficient outcome.

Under these circumstances, local government might use statutory powers to improve outcomes. In the United Kingdom, for example, local councils are responsible for investigating complaints about excessive noise from $11 \mathrm{pm}$ to $7 \mathrm{am}$, and can impose fines or prosecute if the noise is not kept below fixed limits (DEFRA 2017). In the property development example, a council might fund a local development agency to negotiate incentives for developers to create neighbourhood regeneration projects that generate positive externalities.

\section{Economic Public Goods}

A good or service is an economic public good if it has two characteristics (Samuelson 1954). First, using the good or service must not prevent other persons from benefiting from the same item simultaneously. This is termed nonrivalry in consumption. Second, if an economic public good is provided to any person, then it must not be possible to prevent others from enjoying its benefits; the good or service is said to be non-excludable. ${ }^{1}$ 
A good example is street lighting installed by a local council to increase safety at night. One person using the street lighting does not prevent others from doing likewise at the same time (non-rivalry in consumption). When the lights are operating, it is not possible to prevent anyone in the streets from using them (non-excludable).

The first characteristic means that a small financial sacrifice by each person in a community can produce large wellbeing benefits for all residents. Consider a city with a population of 400,000 adults. If each adult agrees to contribute $£ 20 \mathrm{a}$ year for street lighting, the result is $£ 8$ million available to fund an annual service whose benefits can be enjoyed by all, because the street lighting is non-rival in consumption. Thus, each resident can access services costing $£ 8$ million to operate, while paying only $£ 20$.

However, because the services are non-excludable, economic public goods are unlikely to be funded by voluntary collaboration, at least not beyond a small scale. Suppose a resident is asked to volunteer $£ 20$ for the street lighting. The person might decline, judging that an extra $£ 20$ for operating an $£ 8$ million system would not be as beneficial as an extra $£ 20$ of personal spending. Other residents might reason in the same way and so the lighting project would be underfunded. A market firm trying to sell the service to individual residents would face the same issue.

This is the free-rider problem: "Not all people can be expected to contribute voluntarily to a good cause, and any voluntary system is likely to produce too little of the public good" (Dawes and Thaler 1988, p. 196). ${ }^{2}$ It provides a rationale for government, which can resolve the problem by its authority to collect compulsory taxes and rates. As the street lighting example illustrates, economic public goods have the potential to deliver large benefits to residents in return for a relatively small tax levied on each property owner or income-earner.

This reasoning does not require a local government to collect its own revenue. In England, for example, Parishes and Charter Trustees charge a precept collected on their behalf by larger billing authorities (DCLG 2017, pp. 4-5). Also, local authorities receive funds through central government. Some funds are from general taxation (including grants tied to specific purposes such as education or policing) and some are from the rates on non-domestic properties (also known as business rates) that are collected and distributed according to rules set by central government.

Figure 6.1 shows the transfers from central to local government in England from 1997-1998 to 2016-2017. The data are measured using 2016-2017 prices 


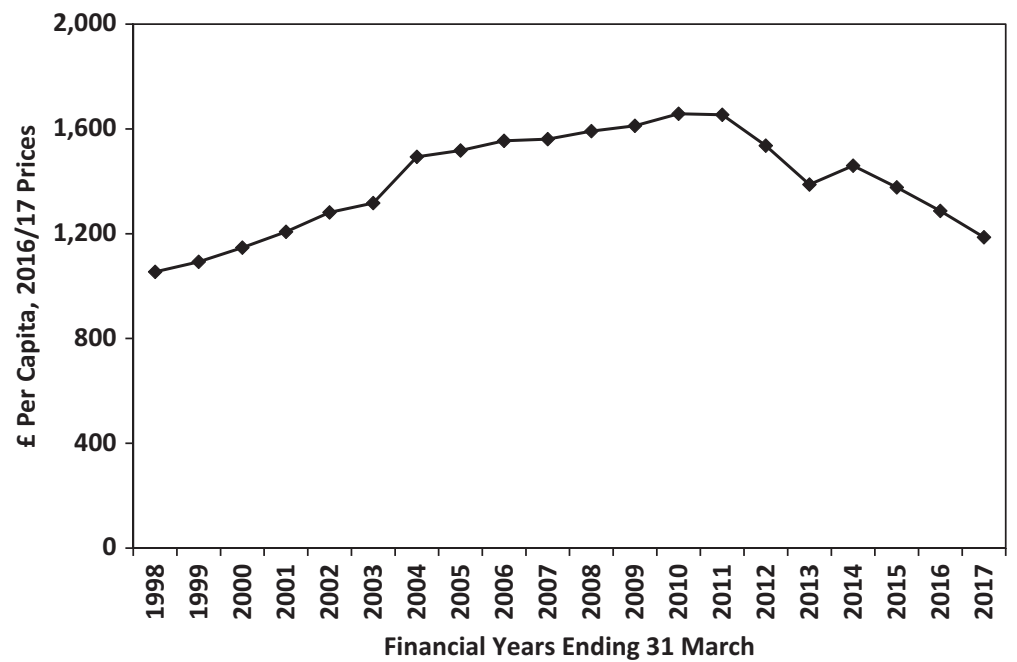

Fig. 6.1 Transfers from central government to local government, per capita, England, 1997-1998 to 2016-2017. (Note: Transfers include government grants and non-domestic rates; the values are presented at 2017 GDP Deflator prices and have been divided by midyear population for England in the previous calendar year. Source: Calculated from DCLG (2014, Table 3.2e) and DCLG (2017, Table 3.2a) using ONS estimates for the GDP Deflator and mid-year population)

to remove the impact of inflation, and are shown in per capita terms to account for increased demand on services due to population growth. Comparisons between years must still be made cautiously because policy changes can affect the need for local government finance (such as the increase in academy schools, which are funded by central rather than local government). Nevertheless, three distinctive periods are clear in the graph.

First, per capita transfers grew strongly between 1997-1998 and 2003-2004, from just under $£ 1100$ to nearly $£ 1500$, as central government sought to address longstanding problems of social exclusion in some parts of the United Kingdom. Second, transfers then rose at a slower rate, peaking at $£ 1658$ per person in 2009-2010. Third, as part of the central government's austerity measures after the Global Financial Crisis, a sharp fall resulted in per capita transfers reducing to $£ 1186$ in $2016-2017$. This was 28.5 per cent lower than in 2009-2010.

The scale of these cuts has put pressure on the ability of local governments to fund public goods and services for residents (Kennett et al. 2015, p. 640; Hastings et al. 2015). Further, this burden has not been distributed evenly; 
instead, there was a marked association with deprivation: "Between 2010/11 and 2013/14, authorities in the least deprived quintile lost $16 \%$ of their spending power compared with $21 \%$ for those in the most deprived three quintiles" (Bailey et al. 2015, pp. 574-575; see also Keep and Berman 2013, p. 10; Meegan et al. 2014, pp. 141-142).

The changes were designed to support the government's prioritisation of economic growth, discussed in Chap. 1 . This can be illustrated with the policy change for non-domestic rates collected from businesses. These were previously distributed to local governments using a formula based on each authority's relative needs and ability to raise income locally (Keep and Berman 2011, pp. 5-8). The Local Government Finance Act 2012 introduced a new scheme, under which each local authority receives a greater or lesser share depending on whether the real value of its local business rates is increasing or falling (Keep and Berman 2013, section 6).

The new scheme aims to stimulate economic growth by creating incentives for an authority to support local economic development, since the authority now retains a share of any increase in local business rates (idem, p. 31). At the same time, however, the scheme creates greater financial risks for local authorities (National Audit Office 2013, par. 3.17). Further, some local authorities face higher risks than others, because they have fewer opportunities for fostering local economic growth.

Paul Krugman, for example, introduced the theory of agglomeration economics to show how modern technologies can result in situations where "manufactures production will tend to concentrate where there is a large market, but the market will be large where manufactures production is concentrated" (Krugman 1991, p. 486). ${ }^{3}$ This means that patterns of strong economic growth in large cities, accompanied by relative deprivation in other regions, tend to persist (McCann 2008).

Several authors have argued that the financial cutbacks imposed on local governments are part of "the great risk shift" in recent years from social security to individual responsibility. ${ }^{4}$ Hastings et al. (2015, p. 618), for example, place the cuts within a wider objective for local government "to behave more entrepreneurially; to take on more responsibility for economic growth and the distribution of benefits; and to take on new risks in relation both to the demands placed on services such as social care and for balancing budgets". They conclude that England's local government "will have to change to a very substantial extent" (ibid), which provides a context for the following analysis on distinctive contributions local government can make to wellbeing. 


\section{Local Government, Co-production and Capabilities}

As noted earlier, there is no guarantee that local and national governments will always promote wellbeing effectively, even in well-functioning democracies. As Downs (1957, p. 149) was one of the first to analyse, "apathy among citizens towards elections, ignorance of the issues, the tendency of parties in a two-party system to resemble each other, and the anti-consumer bias of government action can all be explained logically as efficient reactions to imperfect information in a large democracy".

Buchanan and Tullock (1962) have proposed constitutional democracy as a system for mitigating some of these tendencies by allowing majority decisionmaking for ordinary issues of the day, while requiring all decisions to satisfy rules that have been codified in a higher-level document that is hard to change. For local government, this system is achieved through State legislation defining its duties and powers. In England, for example, Section 2 of the Local Government Act 2000 used language for this purpose that resonates with major themes of this book:

Every local authority are to have power to do anything which they consider is likely to achieve any one or more of the following objects-

(a) the promotion or improvement of the economic well-being of their area,

(b) the promotion or improvement of the social well-being of their area, and

(c) the promotion or improvement of the environmental well-being of their area.

Authorities made limited use of that wellbeing power, however, tending to rely on other powers that were more specific and so less open to legal challenge (DCLG 2008a, b). The Localism Act 2011 therefore replaced the wellbeing power with a general power of competence: "A local authority has power to do anything that individuals generally may do." This phrase gives local authorities scope for a wide range of initiatives on behalf of communities (Sandford 2016), but obscures the key idea in Proposition 16 that governments have distinctive capabilities for contributing to enhanced wellbeing, beyond "anything that individuals generally may do".

There remains the question of the division of responsibility between local and central governments. The principle of subsidiarity holds that "decisions should be made at the lowest possible spatial scale - being closest to the people affected" (Wills 2016, p. 11). This principle helps guide the allocation of responsibilities 
at different levels of government, as enshrined, for example, in the Treaty on European Union, signed at Maastricht on 7 February 1992 (Article 5, Clause 3):

Under the principle of subsidiarity, in areas which do not fall within its exclusive competence, the Union shall act only if and in so far as the objectives of the proposed action cannot be sufficiently achieved by the Member States, either at central level or at regional and local level, but can rather, by reason of the scale or effects of the proposed action, be better achieved at Union level.

The policy of having decision-making closest to the people affected is termed localism. It has a long history in the United Kingdom (Lyons 2007, pp. 45-49; Wilson and Game 2011; Wills 2016). An implication is that if a public initiative can be greatly improved by local residents actively participating in its design or implementation, then this is a reason for the initiative to be overseen by local rather than central government (Lyons 2007, par. 2.8).

This insight was explored in the research of Nobel laureate Elinor Ostrom (1990, 2005, 2010), who demonstrated how co-production of public services by local residents and local government officials, respecting different levels and nodes of decision-making in local communities, can result in positive outcomes for wellbeing. A good summary is the following statement (Ostrom 1996, p. 1073):

By coproduction, I mean the process through which inputs used to produce a good or service are contributed by individuals who are not "in" the same organization. ... All public goods and services are potentially produced by the regular producer and by those who are frequently referred to as the client. The term "client" is a passive term. Clients are acted upon. Coproduction implies that citizens can play an active role in producing public goods and services of consequence to them.

Note that Ostrom placed persons at the centre of their own lives in a way that resonates strongly with Sen's capabilities approach (Tully 2013). Indeed, her Nobel Prize lecture criticised policies imposed on communities as if "the momentum for change must come from outside the situation rather than from the self-reflection and creativity of those within a situation to restructure their own patterns of interaction" (Ostrom 2010, p. 648).

An important application is place-based regional economic development. Barca et al. (2012, p. 149) observe: "The place-based argument suggests that development strategies should thus focus on mechanisms which build on local capabilities and promote innovative ideas through the interaction of local and general knowledge and of endogenous and exogenous actors in the design and 
delivery of public policies". This accepts the importance of insiders and outsiders interacting in policy design and delivery, and emphasises local capabilities (see also Barca 2009; OECD 2009a, b).

Recall that the previous chapter explained how market firms combine different types of capital to maintain specialist capabilities for supplying goods and services (Proposition 14). Similarly, although at a higher level of generality, regions can develop capabilities for wellbeing as a result of integrated investment in the seven capitals analysed in this book. ${ }^{5}$ This observation is expressed in Proposition 17.

Proposition 17 Local government, sharing leadership with other actors in their communities, can develop and sustain regional capabilities for wellbeing through integrated investment in different types of capital.

Thus, public sector investments in large-scale physical capital projects typically involve regional infrastructure strategies (see, e.g., Solé-Ollé et al. 2012). Similarly, regional skills ecosystems aim to connect human capital investment with demands for labour skills by local industries (Finegold 1999; Hall and Lansbury 2006; Buchanan and Jakubauskas 2010; Dalziel 2015, 2017). Further, regional innovation systems are designed to support the expansion and utilisation of knowledge capital to strengthen regional competitive advantage (Cooke 1992; de la Mothe and Paquet 1998; Asheim and Gertler 2005; Corrocher and Cusmano 2014).

Recent scholarship recognises the value of integrating these types of strategies. Crescenzi and Rodríguez-Pose (2012), for example, found that isolated investments by the European Union in transport infrastructure projects had shown little evidence of improved regional growth. They therefore concluded that transport infrastructure should be linked to "more integrated and inclusive development policies based on human capital and innovation" (idem, p. 508). This echoes similar recommendations by the OECD (2009a, pp. 17-18).

Strategies for investment in other types of capital can also be beneficial. Considering social capital, Malecki (2012, p. 1028) cites Rutten and Boekema (2007) to suggest that "regional social capital is what transforms technology into regional economic development through regional innovation networks". Warner $(1999,2001)$ explains how local government can foster social capital, but concludes both papers with the observation that deeper structural issues-economic and political, as well as social issues-impact on local wellbeing, so that a focus on social capital development is only one aspect of a broader transformation required in local government institutions. 
Similarly, investment in cultural capital is important for place-shaping, defined as "the creative use of powers and influence to promote the general well-being of a community and its citizens" (Lyons 2007, par. 2.43). This includes local government initiatives that support creative lives and the vibrancy of creative endeavours (Florida 2002, p. 232). ${ }^{6}$ Local governments pay attention to the ongoing renewal of heritage in public spaces (Graham 2002; Carmona 2014), as well as creating spaces for communities to engage with each other through programmes such as intercultural cities (Wood and Landry 2008; Cantle 2012; Zapata-Barrero 2015; ICC 2016).

A strong theme in regional policy is the importance of connections beyond a region, including with other regions, with central government and with the global market economy (Harrison 2013; McCann 2016, pp. 10-13). An important driver of European Union cohesion policy, for example, is the smart specialisation concept (Foray 2006; Foray et al. 2009; OECD 2013; Foray 2015; McCann and Ortega-Argilés 2015). This concept proposes that regions can be helped to identify areas of research and development where they have strengths and opportunities based on their existing capabilities and connections to the global market economy. Chap. 8 of this book will discuss connections of this nature under the heading of diplomatic capital.

Finally, all local governments operate in particular places with specific environmental characteristics requiring management. The following section addresses this important feature under the heading of natural capital.

\section{Natural Capital}

The term natural capital is widely used (Schumacher 1973, p. 2; Jansson et al. 1994; Helm 2015), but not always accepted. The metaphor of "capital" is associated with four key elements of an item:

1. The item is an asset, which may be owned privately (e.g., human capital, embodied cultural capital and private physical capital) or collectively (e.g., material cultural capital, social capital and public physical capital).

2. The item provides ongoing services that can be used by persons, organisations and communities to enhance wellbeing.

3. The item has a tendency to deteriorate in quantity or quality over time.

4. The stock of the item can grow through well-designed investment, which always has an opportunity cost. 
The natural environment clearly meets items 2, 3 and 4 in this list. Nature provides essential services for human wellbeing. These are sometimes called ecosystem services (Costanza et al. 1997; Boyd and Banzhaf 2007; Fisher et al. 2009), although there is disagreement about how their economic value should be calculated, if at all (Boehnert 2016, pp. 404-40). Human activity is having detrimental impacts on environmental quality. These impacts can be mitigated through costly investment.

The first item in the list is open to challenge. The suggestion that nature is an asset owned by humans seems to overlook that we humans are a subset of nature (Schumacher 1973, p. 2). Professor Brian Cox, Fellow of the Royal Society and recipient of the 2010 Kelvin Medal and Prize awarded by the Institute of Physics, has expressed this reality on a cosmic scale (Cox and Cohen 2011, p. 135):

When we look out into space, we are looking into our own origins, because we are truly children of the stars. Written into every atom and every molecule of our bodies is the entire history of the Universe.

Hence, to treat nature as a type of capital can be "a procedure by which the higher is reduced to the level of the lower and the priceless is given a price" (Schumacher 1973, p. 46). Boehnert (2016, p. 404) similarly argues that there are deep philosophical objections to the idea that nature might be considered a subsystem of the economy.

The global ecological commons are the source of life and the basis for all activities-economic and noneconomic. Economics is a construct made possible by ecological processes. Ecological processes are simply too complex to be captured absolutely through financial valuation processes because they are the context of economics, not a subsystem of economics...

Some scholars therefore argue that nature has an intrinsic value, independent of the instrumental value to human wellbeing resulting from the provision of ecosystem services (Batavia and Nelson 2017; Piccolo 2017).

These points can be accepted while still retaining a place for the metaphor of natural capital. It would be folly to suggest that all nature, reaching out to the edges of the Universe, is encapsulated within this metaphor. Rather, the metaphor refers only to the interaction of nature with human activities, which is what makes nature subject to items 2, 3 and 4 in the above list. Since these items are profoundly important for the natural environment and for human wellbeing, natural capital should not be excluded from a wellbeing economics framework. 
This is well discussed by Dieter Helm (2015). Helm makes the point that natural damage from human activity is accelerating. This will continue, since current trends suggest that the global economy could multiply perhaps 16 times by the end of the century. Consequently, an unavoidable issue for economic policy is how much effort should be spent preserving and enhancing the environment: "Not much will be left on a business-as-usual basis, and current policies are utterly feeble when confronted with this scale of destruction coming down the track" (idem, p. 5). This is expressed in the final proposition for this chapter.

Proposition 18 Human activity can diminish ecosystem services provided by the natural environment, and so investment in natural capital is required to maintain and enhance wellbeing.

The question arises: Who owns this problem? This is the sense in which arrangements must be made for the ownership of natural capital (the first key element of the capital metaphor listed above). It is not ownership in the sense of assigning exclusive property rights, but ownership in the sense of exercising stewardship by managing investment in natural capital required to maintain and enhance its quality.

Who owns this problem depends on the scale of a particular investment decision. Issues such as climate change affect the whole global community; hence, it is the major focus of Chap. 8. At the local level, all communities have their own natural capital investment decisions to make. These are typically made through co-production with local government services to invest in amenities such as open spaces, community parks, the countryside, natural waterways, protected coastlines, green spaces in cities and good air quality.

\section{Conclusion}

Local government has distinctive capabilities for improving wellbeing, primarily through its ability to address the free-rider problem in the provision of economic public goods and externalities in voluntary transactions. Local authorities provide a range of facilities and services that would otherwise be under-provided.

Best outcomes are achieved through co-production of public services by local residents and local government officials, respecting different levels and nodes of decision-making in local communities. An important application is that a local government, sharing leadership with other actors in their communities, can develop and sustain regional capabilities for wellbeing (including, 
but not restricted to, regional economic development) through integrated investment in different types of capital. This includes investment in natural capital, since ecosystem services provided by the environment are being diminished by human activity.

Local governments are most effective where public decision-making needs to be close to the people affected. In other cases of public goods and services, a larger scale at the national level is more sensible. Chap. 7 therefore turns to the Nation State and wellbeing.

\section{Notes}

1. If an item is rival in consumption but is non-excludable, this gives rise to "The Tragedy of the Commons" (Hardin 1968). This possibility will be discussed in Chap. 8 as part of the analysis of climate change.

2. McMillan (1979) provides an overview of mechanisms proposed by economists for mitigating the free-rider problem.

3. This theory is the starting point for modern economic geography (Krugman 2008, p. 344). The feature that gives rise to this effect is termed increasing returns to scale, meaning that if all inputs into production double, then the volume of output increases by more than double.

4. The cutbacks in funding mean that local authorities are forced to reduce their services, shifting risks to residents. See Meegan et al. (2014); Bailey et al. (2015), Hastings et al. (2015), Kennett et al. (2015) and Scott (2015). Hacker (2008) introduced the term in a US context.

5. Sotarauta (2005) used the theory of the dynamic capabilities of firms to discuss the development of a region's leadership capabilities. Note that place-based policies are not universally supported. Two high-profile critiques were provided by Glaeser and Gottlieb (2008) and World Bank (2009).

6. An impact of austerity measures in the United Kingdom has been significant withdrawals of local government subsidies from arts and culture activities (Hastings et al. 2015, p. 611).

\section{References}

Asheim, Bjørn T., and Meric S. Gertler. 2005. The Geography of Innovation: Regional Innovation Systems. In The Oxford Handbook of Innovation, ed. Jan Fagerberg and David C. Mowery, 291-317. Oxford: Oxford University Press.

Bailey, Nick, Glen Bramley, and Annette Hastings. 2015. Symposium Introduction:

Local Responses to 'Austerity'. Local Government Studies 41 (4): 571-581. 
Barca, Fabrizio. 2009. An Agenda for a Reformed Cohesion Policy: A Place-Based Approach to Meeting European Union Challenges and Expectations. Independent report prepared for the Commissioner for Regional Policy, European Commission. http://ec.europa. eu/regional_policy/archive/policy/future/barca_en.htm. Accessed 29 Dec 2017.

Barca, Fabrizio, Philip McCann, and Andrés Rodríguez-Pose. 2012. The Case for Regional Development Intervention: Place-based versus Place-neutral Approaches. Journal of Regional Science 52 (1): 134-152.

Batavia, Chelsea, and Michael Paul Nelson. 2017. For Goodness Sake! What is Intrinsic Value and Why Should We Care? Biological Conservation 209: 366-376.

Baumol, William J. 1972. On Taxation and the Control of Externalities. American Economic Review 62 (3): 307-322.

Boehnert, Joanna. 2016. The Green Economy: Reconceptualizing the Natural Commons as Natural Capital. Environmental Communication 10 (4): 395-417.

Boyd, James, and Spencer Banzhaf. 2007. What are Ecosystem Services? The Need for Standardized Environmental Accounting Units. Ecological Economics 63 (2-3): 616-6126.

Buchanan, James, and Gordon Tullock. 1962. The Calculus of Consent: Logical Foundations of Constitutional Democracy. Ann Arbor, MI: University of Michigan Press.

Buchanan, John, and Michelle Jakubauskas. 2010. The Political Economy of Work and Skill in Australia: Insights from Recent Applied Research. In Beyond Skill: Institutions, Organisations and Human Capability, ed. Jane Bryson, 32-57. London: Palgrave Macmillan.

Cantle, Ted. 2012. Interculturalism: The New Era of Cohesion and Diversity. Houndmills: Palgrave Macmillan.

Carmona, Matthew. 2014. The Place-shaping Continuum: A Theory of Urban Design Process. Journal of Urban Design 19 (1): 2-36.

Coase, Ronald H. 1960. The Problem of Social Cost. Journal of Law and Economics 3 (1): $1-44$.

Cooke, Philip. 1992. Regional Innovation Systems: Competitive Regulation in the New Europe. Geoforum 23 (3): 365-382.

Corrocher, Nicoletta, and Lucia Cusmano. 2014. The 'KIBS Engine' of Regional Innovation Systems: Empirical Evidence from European Regions. Regional Studies 48 (7): $1212-1226$.

Costanza, Robert, Ralph d'Arge, Rudolf de Groot, Stephen Farberk, Monica Grasso, Bruce Hannon, Karin Limburg, Shahid Naeem, Robert V. O'Neill, Jose Paruelo, Robert G. Raskin, Paul Sutton, and Marjan van den Belt. 1997. The Value of the World's Ecosystem Services and Natural Capital. Nature 387: 253-260.

Cox, Brian, and Andrew Cohen. 2011. Wonders of the Universe. Glasgow: Collins.

Crescenzi, Riccardo, and Andrés Rodríguez-Pose. 2012. Infrastructure and Regional Growth. Papers in Regional Science 91 (3): 487-513.

Dalziel, Paul. 2015. Regional Skill Ecosystems to Assist Young People Making Education Employment Linkages in Transition from School to Work. Local Economy 30 (1): 53-66. 
. 2017. Education and Qualifications as Skills. In The Oxford Handbook of Skills and Training, ed. John Buchanan, David Finegold, Ken Mayhew, and Chris Warhurst, 143-160. Oxford: Oxford University Press.

Dawes, Robyn M., and Richard H. Thaler. 1988. Anomalies: Cooperation. Journal of Economic Perspectives 2 (3): 187-197.

DCLG. 2008a. Evaluation of the Take-up and Use of the Well-Being Power: Research Summary. London: Department for Communities and Local Government.

- 2008b. Practical Use of the Well-Being Power. London: Department for Communities and Local Government.

- 2014. Local Government Financial Statistics England, No. 24 2014. London: Department for Communities and Local Government.

- 2017. Local Government Financial Statistics England, No. 27 2017. London: Department for Communities and Local Government.

de la Mothe, John, and Gilles Paquet, eds. 1998. Local and Regional Systems of Innovation. New York: Kluwer Academic Publishers.

DEFRA. 2017. Noise Nuisances: How Councils Deal with Complaints Department for Environment, Food \& Rural Affairs webpage accessed 30 December 2017 at https:// www.gov.uk/guidance/noise-nuisances-how-councils-deal-with-complaints.

Downs, Anthony. 1957. An Economic Theory of Political Action in a Democracy. Journal of Political Economy 65 (2): 135-150.

Finegold, David. 1999. Creating Self-sustaining, High-skill Ecosystems. Oxford Review of Economic Policy 15 (1): 60-81.

Fisher, Brendan, R. Kerry Turner, and Paul Morling. 2009. Defining and Classifying Ecosystem Services for Decision Making. Ecological Economics 68 (3): 643-653.

Florida, Richard. 2002. The Rise of the Creative Class: And How It's Transforming Work, Leisure, Community and Everyday Life. New York: Perseus Book Group.

Foray Dominique. 2006. Globalization of R\&D: Linking Better the European Economy to "Foreign" Sources of Knowledge and Making EU a More Attractive Place for R\&D Investment. Knowledge Economists Policy Brief No. 1. http://ec.europa.eu/ invest-in-research/monitoring/knowledge_en.htm. Accessed 10 Jan 2018.

- 2015. Smart Specialisation: Opportunities and Challenges for Innovation Policy. London: Routledge.

Foray Dominique, Paul A. David and Bronwyn Hall. 2009. Smart Specialisation - The Concept. Knowledge Economists Policy Brief No. 9. http://ec.europa.eu/invest-inresearch/monitoring/knowledge_en.htm. Accessed 10 Jan 2018.

Glaeser, Edward L., and Joshua D. Gottlieb. 2008. The Economics of Place-making Policies. Brookings Papers on Economic Activity (1): 155-239.

Graham, Brian. 2002. Heritage as Knowledge: Capital or Culture? Urban Studies 39 (5-6): 1003-1017.

Hacker, Jacob S. 2008. The Great Risk Shift: The New Economic Insecurity and the Decline of the American Dream. Revised and expanded edition. New York: Oxford University Press. 
Hall, Richard, and Russell D. Lansbury. 2006. Skills in Australia: Towards Workforce Development and Sustainable Skill Ecosystems. Journal of Industrial Relations 48 (5): 575-592.

Hardin, Garrett. 1968. The Tragedy of the Commons. Science 162 (3859): 1243-1248. Harrison, John. 2013. Configuring the New 'Regional World': On being Caught between Territory and Networks. Regional Studies 47 (1): 55-74.

Hastings, Annette, Nick Bailey, Maria Gannon, Kirsten Besemer, and Glen Bramley. 2015. Coping with the Cuts? The Management of the Worst Financial Settlement in Living Memory. Local Government Studies 41 (4): 601-621.

Helm, Dieter. 2015. Natural Capital: Valuing the Planet. New Haven/London: Yale University Press.

ICC. 2016. Intercultural Cities Annual Report 2016: Sharing Our Cities Sharing the Future. Council of Europe Intercultural Cities Programme. https://rm.coe. int/16806c9674. Accessed 6 Oct 2017.

Jansson, AnnMari, Monica Hammer, Carl Folke, and Robert Costanza, eds. 1994. Investing in Natural Capital: The Ecological Economics Approach to Sustainability. Washington, DC: Island Press.

Keep, Matthew and Gavin Berman. 2011. The Local Government Finance Settlement 2011-2013. Research Paper 11/16. London: House of Commons Library.

- 2013. The Local Government Finance Settlement 2013/14 and 2014/15. Research Paper 13/10. London: House of Commons Library.

Kennett, Patricia, Gerwyn Jones, Richard Meegan, and Jaccqui Croft. 2015. Recession, Austerity and the 'Great Risk Shift': Local Government and Household Impacts and Responses in Bristol and Liverpool. Local Government Studies 41 (4): 622-644.

Krugman, Paul. 1991. Increasing Returns and Economic Geography. Journal of Political Economy 99 (3): 483-499.

- 2008. The Increasing Returns Revolution in Trade and Geography. Nobel Prize speech, republished in Karl Grandin, Ed. The Nobel Prizes 2008. Stockholm: Nobel Foundation, 2009, pp. 335-348.

Le Grand, Julian. 1991. The Theory of Government Failure. British Journal of Political Science 21 (4): 423-442.

Locke, John. 1690. Two Treatises of Government, Book II. Available at www.gutenberg. org/ebooks/7370.

Lyons, Sir Michael. 2007. Place-shaping: A Shared Ambition for the Future of Local Government. London: The Stationery Office.

Malecki, Edward J. 2012. Regional Social Capital: Why it Matters. Regional Studies 46 (8): 1023-1039.

McCann, Philip. 2008. Globalization and Economic Geography: The World Is Curved, Not Flat. Cambridge Journal of Regions, Economy and Society 1 (3): 351-370.

- 2016. The UK Regional-National Economic Problem: Geography, Globalisation and Governance. Abingdon: Routledge. 
McCann, Philip, and Raquel Ortega-Argilés. 2015. Smart Specialization, Regional Growth and Applications to European Union Cohesion Policy. Regional Studies 49 (8): 1291-1302.

McMillan, John. 1979. The Free-Rider Problem: A Survey. Economic Record 55 (2): 95-107. Meegan, Richard, Patricia Kennett, Gerwyn Jones, and Jacqui Croft. 2014. Global Economic Crisis, Austerity and Neoliberal Urban Governance in England. Cambridge Journal of Regions, Economy and Society 7 (1): 137-153.

National Audit Office. 2013. Financial Sustainability of Local Authorities. Report by the Comptroller and Auditor General, HC 888. London: The Stationery Office.

OECD. 2009a. How Regions Grow: Trends and Analysis. Paris: Organisation for Economic Cooperation and Development.

- 2009b. Regions Matter: Economic Recovery, Innovation and Sustainable Growth. Paris: Organisation for Economic Cooperation and Development.

- 2013. Innovation-driven Growth in Regions: The Role of Smart Specialisation. Paris: Organisation for Economic Cooperation and Development.

Olson, Mancur. 1965. The Logic of Collective Action: Public Goods and the Theory of Groups. Cambridge, MA: Harvard University Press.

Ostrom, Elinor. 1990. Governing the Commons: The Evolution of Institutions for Collective Action. Cambridge: Cambridge University Press.

- 1996. Crossing the Great Divide: Coproduction, Synergy, and Development. World Development 24 (6): 1073-1087.

- 2005. Understanding Institutional Diversity. Princeton, NJ: Princeton University Press.

- 2010. Beyond Markets and States: Polycentric Governance of Complex Economic Systems. American Economic Review 100 (3): 641-672.

Piccolo, John J. 2017. Intrinsic Values in Nature: Objective Good or Simply Half of an Unhelpful Dichotomy? Journal for Nature Conservation 37: 8-11.

Pigou, Arthur Cecil. 1932. The Economics of Welfare. 4th ed. London: Macmillan.

Rutten, Roel, and Frans Boekama. 2007. Regional Social Capital: Embeddedness, Innovation Networks and Regional Economic Development. Technological Forecasting and Social Change 74 (9): 1834-1846.

Samuelson, Paul A. 1954. The Pure Theory of Public Expenditure. Review of Economics and Statistics 36 (4): 387-389.

Sandford, Mark. 2016. The General Power of Competence. Briefing Paper Number 05687. London: House of Commons Library.

Schumacher, Ernst F. 1973. Small is Beautiful: Economics as if People Mattered. New York: Harper and Row.

Scott, Karen. 2015. Happiness on Your Doorstep: Disputing the Boundaries of Wellbeing and Localism. The Geographical Journal 181 (2): 129-137.

Solé-Ollé, Albert, Andreas Stephan, and Timo Valilä. 2012. Introduction: Productivity and Financing of Regional Transport Infrastructure. Papers in Regional Science 91 (3): $481-485$. 
Sotarauta, Markku. 2005. Shared Leadership and Dynamic Capabilities in Regional Development. In Regionalism Contested: Institution, Society and Governance, ed. Iwona Sagan and Henrik Halkier, 53-72. Farnham: Ashgate.

Tully, James. 2013. Two Ways of Realizing Justice and Democracy: Linking Amartya Sen and Elinor Ostrom. Critical Review of International Social and Political Philosophy 16 (2): 220-232.

Warner, Mildred. 1999. Social Capital Construction and the Role of the Local State. Rural Sociology 64 (3): 373-393.

- 2001. Building Social Capital: The Role of Local Government. Journal of SocioEconomics 30 (2): 187-192.

Wills, Jane. 2016. Locating Localism: Statecraft, Citizenship and Democracy. Bristol: Policy Press.

Wilson, David, and Chris Game. 2011. Local Government in the United Kingdom. 5th ed. Houndmills: Palgrave Macmillan.

Wolf, Charles, Jr. 1979. A Theory of Nonmarket Failure: Framework for Implementation Analysis. Journal of Law and Economics 22 (11): 107-139.

- 1989. Markets or Governments: Choosing Between Imperfect Alternatives. Cambridge, MA: MIT Press.

Wood, Phil, and Charles Landry. 2008. The Intercultural City: Planning for Diversity Advantage. London: Earthscan.

World Bank. 2009. Reshaping Economic Geography: Economic Development Report 2009. Washington, DC: World Bank.

Zapata-Barrero, Ricard. 2015. Interculturalism in Cities: Concept, Policy, and Implementation. Cheltenham: Edward Elgar.

Open Access This chapter is licensed under the terms of the Creative Commons Attribution 4.0 International License (http://creativecommons.org/licenses/by/4.0/), which permits use, sharing, adaptation, distribution and reproduction in any medium or format, as long as you give appropriate credit to the original author(s) and the source, provide a link to the Creative Commons license and indicate if changes were made.

The images or other third party material in this chapter are included in the chapter's Creative Commons license, unless indicated otherwise in a credit line to the material. If material is not included in the chapter's Creative Commons license and your intended use is not permitted by statutory regulation or exceeds the permitted use, you will need to obtain permission directly from the copyright holder.

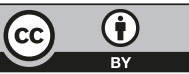

